\title{
NARASI PERSUASI SOCIAL MEDIA INFLUENCER DALAM MEMBANGUN KONSEP KECANTIKAN DAN KEPERCAYAAN DIRI
}

\author{
Yosieana Ligariaty $^{1^{*}}$ dan Irwansyah $^{2}$ \\ 1,2Universitas Indonesia, Depok - Indonesia \\ yosieana.ligariaty01@ui.ac.id
}

\begin{abstract}
The existence of social media allows the emergence of social media influencers where in turn they have an impact on social media users. This can happen by bringing up new messages or raising issues about a particular subject. One of them is the topic of the concept of beauty and its relation to self-confidence. Moreover, with the existence of social media influencers who carry out information dissemination activities by compiling and creating content related to the concept of beauty and its relation to self-confidence. By using persuasive narratives, social media influencers build different beauty concepts that can even be contrary to concepts that have been developing in society. The purpose of writing this research is focused on providing an understanding to the wider community, about the narratives used by social media influencers in persuading and penetrating new messages to the public, especially with regard to the concept of ideal beauty related to hairstyles. Through the method of qualitative content analysis techniques to observe the messages conveyed by social media influencers, related to a number of important aspects. The use of qualitative content analysis allows the writer to see the content of the message more deeply, through understanding the meaning of the message
\end{abstract}

Keywords: persuasive narrative, social media influencer, beauty, confidence, instagram

\begin{abstract}
Abstrak
Keberadaan media sosial memungkinkan munculnya social media influencer dimana selanjutnya mereka memiliki dampak terhadap pengguna media sosial. Hal ini dapat terjadi dengan memunculkan pesan- pesan baru atau mengangkat isu mengenai hal tertentu. Salah satunya adalah topik mengenai konsep kecantikan dan kaitannya dengan kepercayaan diri. Terlebih lagi dengan keberadaan social media influencer yang melakukan aktivitas penyebaran informasi dengan menyusun dan membuat konten-konten yang berkaitan dengan konsep konsep kecantikan dan kaitannya dengan kepercayaan diri. Dengan menggunakan narasi persuasi, social media influencer membangun konsep kecantikan yang berbeda bahkan bisa jadi berlawanan dengan konsep yang selama ini berkembang di masyarakat. Tujuan dari penulisan penelitian ini difokuskan pada memberikan pemahaman kepada masyarakat luas, tentang narasi yang digunakan oleh social media influencer dalam mempersuasi serta mempenetrasikan pesan-pesan baru kepada masyarakat terutama berkaitan dengan konsep kecantikan ideal berkaitan dengan gaya rambut. Melalui metode teknik analisis isi kualitatif untuk mengamati pesan-pesan yang disampaikan oleh social media influencer, terkait dengan sejumlah aspek penting. Penggunaan analisis isi kualitatif memungkinkan penulis melihat isi pesan secara lebih dalam, melalui pemahaman makna pesan.
\end{abstract}

Kata Kunci: Narasi persuasif, social media influencer, kecantikan, kepercayaan diri, instagram

\section{PENDAHULUAN}

Digitalisasi sebagai bagian dari kemajuan teknologi, memberikan kesempatan bagi lahirnya internet, yang didefinisikan dalam bahasa Inggris sebagai international connection networking. Konsep ini sendiri dapat dimengerti sebagai jaringan internasional yang memiliki hubungan antara satu dengan yang lainnya. Internet menjadi bagian integral dari globalisasi yang diakibatkan perkembangan pesat dari 
teknologi informasi (Indrawan \& Ilmar, 2018). Dalam era setelah modernisme, seiring dengan munculnya media baru (new media), terjadi perubahan bentuk khalayak media.

Khalayak media lama menjadi kabur atau bahkan seolah-olah menghilang. (Malau, 2011). Fenomena munculnya berbagai kanal media baru di internet juga kerap ditemui dalam keseharian, salah satunya ada pada kemunculan media sosial. Media sosial hasil dari perkembangan teknologi yang berkembang dengan sangat pesat dan dinilai memiliki pengaruh yang cukup besar dalam kehidupan masyarakat. Media sosial bersifat sangat dinamis karena bentuk dan kategorinya selalu berubah seiring dengan perkembangan teknologi. Meskipun demikian, media sosial pada saat ini umumnya terdiri dari weblogs (atau "blogs"), microblogs, situs jejaring sosial, dan situs media-sharing, RSS dan feed sindikasi web lain, wiki, sosial bookmark, mashup, widget, microbloging, dan lain-lain (Supradono \& Hanum, 2011). Indonesia sendiri merupakan salah satu negara dengan penggunaan internet \& populasi pengguna media sosial yang tergolong tinggi. Berdasarkan data dari Hootsuite \& We Are Social pada tahun 2018 mengenai Digital Indonesia - a Snapshot of the Country's Key Digital Statistical Indicators, separuh dari total populasi di Indonesia menggunakan internet untuk menunjang kegiatannya. Ratarata populasi menggunakan internet selama delapan jam dan lima puluh satu menit setiap harinya. Sementara itu, sebanyak $49 \%$ dari populasi Indonesia secara aktif memanfaatkan media sosial untuk berbagai berbagai aspek dalam kehidupan.

Media sosial secara nyata sudah baik disadari ataupun tidak merubah proses komunikasi manusia. Saat sebelum munculnya media sosial, proses komunikasi berbentuk komunikasi tatap muka, komunikasi kelompok, ataupun komunikasi massa. Tetapi dengan terdapatnya pertumbuhan teknologi komunikasi yang terus menjadi mutahir hingga ikatan tatap muka antara manusia pula sudah bisa digantikan oleh ikatan interface ataupun antar- muka dengan "terminal-terminal" teknologi berbentuk komunikasi fitur elektronik mendapatkan kehidupan sendiri. Komentar ini dikemukakan oleh Sherry Turkle tentang layar komputer dimana disebut sebagai second self (Holmes, 2012). Penggunaan media baru dalam hal ini internet serta media sosial dinilai memaksimalkan pengembangan kemampuan media dalam hal sifat personal serta kemudahan untuk diakses oleh khalayak. Kondisi ini mengubah kecenderungan cara masyarakat dalam berkomunikasi, sehingga mayoritas khalayak saat ini menjadikan internet sebagai sarana utama untuk memenuhi kebutuhan informasi, terlebih informasi yang tidak bisa didapatkan dari media-media tradisional.

Keunggulan media sosial dalam memberikan perubahan kepada masyarakat modern berhubungan dengan sifat-sifat karakteristik media sosial itu sendiri yang berhubungan erat dengan sifat-sifat internet. Internet sendiri pada dasarnya merupakan jaringan kerja yang menghubungkan koneksi antar komputer dalam suatu jaringan yang sangat luas. Dimana secara lebih detail, internet merupakan hasil konvergensi teknologi antara teknologi komputerisasi, teknologi informasi, dan teknologi penyimpanan data (Flew, 2018). Konvergensi teknologi tersebut menjadikan internet memiliki sifat interaktif (interactivity) yang tidak dimiliki oleh teknologi komunikasi lainnya. Interaktivitas menjadikan pengguna mampu dan dapat berkomunikasi secara imbal balik menggunakan teknologi internet, bahkan internet memungkinkan masing-masing individu berkomunikasi secara face-to-face menggunakan jaringan internet. Hal inilah yang menjadikan media sosial memberikan implikasi besar terhadap kehidupan masyarakat modern, khususnya bagi pengguna media sosial. 
Setiap platform media sosial pun mempunyai karakteristik unik antara satu dengan lainnya. Misalnya, Instagram yang lebih fokus pada konten berupa foto maupun video serta berbagai fitur yang menawarkan interaktivitas dengan khalayaknya seperti Instagram Stories. Oleh karena itu, media sosial satu ini sering kali digunakan untuk kepentingan pemasaran atau sosialisasi baik terhadap suatu produk maupun organisasi dan aktivitas personal. Secara statistik, instagram merupakan salah satu media sosial yang popular di Indonesia. Dari data yang dilansir oleh Napoleon Cat, pada periode bulan Januari sampai dengan Mei 2020, tercatat pengguna media sosial ini mencapai 69,2 juta orang. Dengan komposisi sebagian besar pengguna Instagram merupakan kaum perempuan. Tercatat jumlah pengguna Instagram dari kalangan perempuan mencapai 50,8 persen, sementara pengguna laki-laki sebesar 49,2 persen. Sifat dinamis yang menjadi ciri media sosial juga dimiliki oleh Instagram sehingga memberikan ruang gerak lahirnya berbagai produk konten yang beragam dan lebih spesifik.

Instagram sendiri merupakan media sosial yang juga populer di kalangan influencer. Instagram memungkinkan terciptanya interaksi antara para influencer dengan pengikutnya. Fitur likes ataupun kolom komentar pada media sosial Instagram inilah yang membuka munculnya interaksi antara para influencer dengan pengikutnya. (Castells, 2013) menyebut hal ini dengan istilah mass-self communication. Instagram merupakan aplikasi media sosial yang muncul pada tahun 2010. Aplikasi ini dapat dijangkau melalui mobile ataupun web. Instagram menyediakan berbagai filter sehingga pengguna dapat mengunggah foto dengan memanfaatkan filter tersebut. Instagram sendiri terus mengembangkan berbagai inovasi dalam jejaring sosial yang berbasis foto dan video. Dari sisi pengguna, Indonesia merupakan salah satu negara dengan jumlah profil bisnis instagram terbanyak di Asia Pasifik, selain Amerika, Brazil, Rusia dan Inggris. Sehingga Indonesia menjadi bagian dari lima negara dengan pemilik profil bisnis Instagram paling besar. Keberadaan influencer khususnya media sosial nampaknya memiliki dampak yang cukup kuat, terutama terhadap generasi muda (Kadekova \& Hoilencinova, 2018) Sweeney (2012) menyatakan bahwa ciri khas generasi millennial adalah media/format agnostic. Generasi ini cenderung menyukai dan menikmati multimedia yang memiliki gerak penuh yang bersifat interaktif dengan warna dan audio.

Social media influencer sendiri ialah suatu sebutan yang merujuk pada keahlian seorang dalam memberitahukan data maupun informasi yang diperuntukan kepada pengikut mereka yang terdapat di media sosial (Elli, 2017). Influencer media sosial dimaknai sebagai tokoh yang dipandang sebagai pemimpin opini di platform media sosial dalam topik yang menarik minat tertentu seperti dalam hal kecantikan, makanan, gaya hidup serta gaya pakaian (Bruns, 2018). Dengan kata lain, influencer dapat dikatakan sebagai seorang aktivis, yang memiliki hubungan secara baik, memiliki dampak, aktif dalam hal mengemukakan pikiran, pendapat serta merupakan tolak ukur bagi para pengikutnya. Kehadiran social media influencer saat ini nampaknya menjadi bagian dari masyarakat modern. Hal ini dilihat karena ia menyediakan sebagian informasi penting yang dibutuhkan oleh khalayak. Social media influencer menjadi kelompok baru yang bertugas memberikan pemahaman hingga mengubah sikap khalayak menggunakan internet atau media sosial (Glucksman, 2017). 
Influencer dikelompokkan berdasarkan jumlah pengikut yang dimiliki di media sosial. Istilah selebriti influencer mengacu pada seseorang yang diyakini berpengaruh karena popularitasnya. Oleh karena itu, menurut (Senft, 2008). Influencer media sosial yang andal tampaknya harus mampu meyakinkan khalayak mereka untuk menerima penawaran atau membeli produk yang diiklankan. Ada tiga hal yang dapat diperhatikan untuk menjadi influencer sosial: reach, relevance, dan resonance. Reach mengacu pada kemampuan untuk menyampaikan konten ke target khalayak. Sedang relevance mengacu pada hubungan yang kuat dengan merek atau topik, dan resonance mengacu pada kemampuan untuk mengarahkan perilaku yang diinginkan khalayak (Elli, 2017).

Selain itu, seorang social media influencer dalam usahanya menyebarkan pemahaman serta mengubah sikap khalayak, membutuhkan kemampuan dan keahlian dalam pengemasan pesan agar dapat mempersuasi khalayak. (Devito, 2011) menyatakan bahwa persuasi merupakan mengutamakan perhatian kepada usaha untuk mengubah atau memperkuat sikap atau kepercayaan khalayak atau upaya mengajak mereka untuk bertindak mengikuti dengan suatu cara tertentu. Lebih lanjut, menurut Crider (Jamiluddin, 2017), terdapat dua syarat yang harus menjadi fokus perhatian dalam menyusun pesan persuasif. Pertama, pesan yang disampaikan harus tidak memiliki makna yang bias. Sedangkan syarat yang kedua adalah, pesan yang disampaikan harus mampu untuk memotivasi. Hal ini berarti dimana suatu pesan yang disusun haruslah mampu mendorong khalayak sasaran dalam menentukan pilihan serta kemauannya sendiri.

Dalam pemberian motivasi ini, biasanya terdapat pemberian bukti, atau pernyataan fakta, informasi, atau bahkan pendapat orang lain yang menguatkan serta mendukung pesan yang disebarluaskan. Dalam kaitannya dengan makna bias menurut Crider (Jamiluddin, 2017) terdapat tiga hal yang harus diperhatikan supaya pesan yang disampaikan tidak memiliki makna bias. Yang pertama adalah pesan yang disampaikan pada khalayak hendaknya tidak mengandung atau berisikan mengenai suatu kebohongan. Serta dalam penyampaian pesan akan lebih baik jika diberi penjelasan secukupnya yang tidak melebar dari fakta/kenyataan mengenai produk atau jasa yang dikomunikasikan. Selanjutnya yang kedua, pesan sebaiknya berisi dua kepentingan sekaligus. Yakni kepentingan yang ingin disampaikan oleh penyampai pesan dan penerima. Dua kepentingan di sini sebaiknya disampaikan secara seimbang. Dimana artinya pesan yang disampaikan benar-benar menunjukkan perbandingan data yang seimbang, baik dari sisi positif maupun juga sisi negatif. Sedangkan yang terakhir adalah dalam mengemas pesan persuasif sebaiknya tidak menggunakan unsur paksaan, baik paksaan secara psikologis maupun fisik.

Dalam teori paradigma naratif milik Walter Fisher, narasi merupakan pengambaran baik secara verbal maupun nonverbal dengan rangkaian peristiwa yang memiliki makna bagi khalayaknya (West et al., 2019). Dengan demikian maka dapat ditarik kesimpulan bahwa tokoh pencerita dan pendengar merupakan unsur yang wajib ada dalam teori ini. Fisher menyatakan bahwa naratif meliputi semua peristiwa dalam komunikasi. Lebih lanjut, ia juga menjelaskan bahwa kehidupan manusia merupakan rangkaian atau susunan kisah-kisah atau cerita-cerita atau naratif (West et al., 2019). Sedangkan persuasi merupakan proses komunikasi yang bersifat kompleks dimana individu atau kelompok mengungkapkan pesan baik secara sengaja maupun tidak sengaja melalui cara-cara verbal dan nonverbal untuk memperoleh respons tertentu dari individu atau kelompok lain Karl, (Usmita, 2007) Sehingga dengan demikian narasi persuasi merupakan penggambaran verbal dan nonverbal dengan rangkaian peristiwa yang dilakukan untuk mendapatkan feedback tertentu. 
Seorang komunikator dalam melakukan narasi persuasi memerlukan beberapa hal yakni kredibilitas, alasan serta emosi (Alvonco, 2014). Dalam hal ini, kredibilitas adalah dimana komunikator harus mampu menunjukkan diri sebagai orang yang dapat percaya dan yang menguasai topik yang dibicarakan. Hal selanjutnya yakni alasan adalah dimana komunikator harus mampu memberikan pertimbangan logis yang berhubungan dengan kebutuhan dan harapan komunikan, bisa juga didukung oleh data yang akurat. Dan yang terakhir yakni emosi dimana komunikator harus memperhatikan emosi dari komunikan sehingga mampu membangun kesamaan pola komunikasi. Lebih lanjut, (Alvonco, 2014) menjelaskan bahwa bentuk penyampaian pesan dalam komunikasi persuasi dibagi menjadi claim, warrant dan data. Claim adalah dimana ketika yang dilakukan menggunakan suatu pernyataan baik secara eksplisit maupun implisit. Sedangkan warrant yaitu merupakan penyampaian pesan yang berupa ajakan namun bukan sebuah paksaan. Yang terakhir yakni data, adalah persuasi yang menggunakan data atau fakta.

Dalam upaya untuk mencapai tujuan utama dari komunikasi persuasi yakni adanya perubahan sikap dan perilaku, maka komunikator harus memperhatikan prinsipprinsip persuasi. Dijelaskan oleh oleh Liliweri (2011) yang dikutip dari pernyataan Robert Cialdini prinsip-prinsip tersebut adalah reciprocation, commitment and consistency, social proof, authority, liking serta scarcity. Reciprocation adalah dimana orang cenderung berusaha kembali kepada situasi yang bersifat aman dan menyenangkan. Hal ini terjadi misalnya ketika masyarakat di masa pandemi ini dimotivasi oleh influencer untuk bersikap sabar dan tetap mematuhi protokol kesehatan supaya pandemi segera mereda dan situasi dapan kembali normal. Dalam prinsip commitment and consistency, persuasi yang dilakukan harus juga memperhatikan aspek komitmen dan konsistensi karena seseorang yang memiliki komitmen tidak suka komitmennya dilanggar. Selanjutnya prinsip social proof adalah dimana seseorang yang berada dalam suatu kelompok memiliki solidaritas lebih dalam menghadapi ancaman atau tantangan yang berasal dari luar kelompok. Prinsip yang keempat adalah authority, dimana prinsip ini berkaitan dengan kondisi orang yang umumnya cenderung patuh pada otoritas meskipun mereka diminta melakukan hal yang tidak mereka suka. Prinsip yang kelima adalah liking, dimana orang lebih mudah dipersuasi oleh orang yang mereka sukai. Prinsip yang terakhir adalah scarcity dimana orang lebih mudah dipersuasi oleh sesuatu yang bersifat langka.

Topik perihal kecantikan memanglah sangat identik serta dekat dengan kalangan wanita. Semenjak dulu kecantikan telah dikonstruksikan oleh warga serta seolah jadi kontrol sosial untuk wanita. Konstruksi sosial tersebut membentuk anggapan wanita haruslah memiliki standar kecantikan yang sempurna dan diakui di mata masyarakat. Kemunculan media seperti televisi membolehkan terbentuk munculnya ide-ide mengenai standar kecantikan lewat film serta iklan, dan lewat figur- figur wanita yang bertubuh sempurna (Melliana, 2006). Dalam perihal tentang konsep kecantikan khususnya rambut, representasi yang sepanjang ini timbul mengenai hal tersebut ditafsirkan dalam penggambaran wanita yang mempunyai rambut yang lurus, bercorak gelap, tidak rontok, tidak berketombe serta tidak bercabang (Suryani, 2020). Fenomena yang timbul, wanita belum dikategorikan cantik dan menawan jika tidak memiliki standar yang sesuai dengan penggambaran yang muncul di media tersebut. Pandangan ini didukung juga melalui hasil riset yang dilakukan oleh Pusat Data Rambut Upjon yang bertajuk "Modern Repunzel: Woman and Their Hair" dinyatakan kalau banyak wanita menghabiskan waktu serta uangnya buat menjaga dan merawat rambut mereka (Berger, 2010).Hingga tidak mengherankan 
bila persoalan mengenai kecantikan ini memiliki daya tarik tersendiri dari sisi untuk industri.

Dalam sejumlah penelitian yang telah dilakukan terdahulu, terdapat alasan pentingnya narasi persuasif. Salah satunya adalah penelitian yang dilakukan oleh Harista, (2017) Penggunaan Bahasa Persuasi di Media Sosial dalam Berdakwah pada Akun Facebook 'Yusuf Mansur (Official). Penelitian ini menyimpulkan bahwa dapat narasi persuasif yang digunakan dalam berdakwah mampu untuk mengubah cara berpikir, memberikan pengaruh yang signifikan bagi kehidupan, serta dapat mengarahkan kepada kebaikan. Menurut Dilla dan Candraningrum (2019:205) dalam penelitian tentang komunikasi persuasif dalam kampanye gerakan anti hoaks oleh komunitas MAFINDO. Penyampaikan kampanye lebih tepat adalah menggunakan perintah halus yang bersifat ajakan atau bujukan. Sehingga dalam pelaksanaannya tidak ada paksaan kepada khalayak untuk mengikuti mengenai apa yang disampaikan.

Lebih jauh, keberadaan Instagram yang mempunyai karakteristik serta ciri tertentu dimana membolehkan kemunculan social media influencer dalam bawa pesan yang bertentangan dengan konsep kecantikan mengenai rambut yang semula diusung oleh media mainstream. Social media influencer dinilai sanggup membagikan pengaruh luas kepada pengguna media sosial, dengan metode memasukkan beberapa pesan baru ataupun mempopulerkan isu tertentu. Perihal itu menjadikan khalayak jadi lebih peduli tentang sesuatu isu tertentu yang muncul, seperti topik mengenai kepercayaan diri atau tentang konsep kecantikan mengenai rambut bagi perempuan. Hal ini nampaknya perlu juga menjadi perhatian bagi seorang sosial media influencer dalam menyusun konten yang akan disampaikan kepada para khalayaknya. Terutama apabila tujuan yang ingin dicapai adalah perubahan dalam sikap maupun perilaku. Gracia yang merupakan seorang social media influencer memiliki tujuan untuk mengubah standar kecantikan yang selama ini ada pada masyarakat Indonesia. Sehingga dirinya perlu mengaplikasikan komunikasi persuasi dalam membangun serta menyebarluaskan konsep terkait kecantikan dan kepercayaan diri. Keberadaan Instagram serta social media influencer memungkinkan munculnya penyampaian pendapat atas ketidaksetujuan atas wacana kecantikan dominan yang selama ini terbentuk di dalam masyarakat. Influencer turut menyuarakan pemikiran mereka mengenai konsep kecantikan selain itu juga berpartisipasi dalam menentang dominasi dalam wacana kecantikan.

Belakangan ini topik bahasan mengenai kepercayaan diri maupun kecantikan menjadi wacana serius dan penting bagi masyarakat modern. Terlebih lagi saat ini kegiatan penyebaran informasi tentang hal tersebut menjadi hal yang penting bagi khalayak, karena itu penting untuk mendalami narasi yang digunakan oleh social media influencer, khususnya pada pesan-pesan yang disajikan dan ditampilkan di dalam media sosial. penelitian ini bertujuan memberikan pemahaman kepada masyarakat luas, tentang narasi yang digunakan oleh social media influencer dalam mempersuasi serta mempenetrasikan pesan-pesan baru kepada masyarakat terutama berkaitan dengan konsep kecantikan ideal berkaitan dengan gaya rambut.

\section{METODOLOGI PENELITIAN}

Penelitian yang memberikan gambaran mengenai bagaimana narasi persuasi yang digunakan oleh social media influencer dalam dalam membangun konsep kecantikan dan kepercayaan diri ini menggunakan pendekatan kualitatif. Untuk dapat memberikan gambaran menyeluruh, pada penelitian ini digunakan metode teknik analisis isi kualitatif. Lebih lanjut, analisis isi merupakan metode penelitian yang digunakan untuk mengetahui kecenderungan isi komunikasi. 
Teknik pengumpulan yang digunakan dalam penelitian ini menggunakan data primer dan sekunder. Data primer didapatkan dari postingan yang ada pada. Data primer yang didapatkan dari akun instagram @ graciaindr berupa tangkapan layar foto beserta caption (narasi) akan ditranskripkan dan diklasifikasikan pada penelitian ini. Sedangkan data sekunder didapatkan dari pemberitaan media mengenai dirinya. Teknik pengolahan dan analisis data dalam penelitian ini terdiri dari tiga proses, yakni proses reduksi data untuk memilih dan menyederhanakan data yang diperlukan atau tidak diperlukan dan mengembangkan sistem kode, lalu proses penyajian data dalam bentuk narasi dan gambar, dan terakhir dilakukan proses menarik kesimpulan atas data yang telah didapatkan. Penelitian yang mengunakan metode analisis isi dalam media sosial pernah dilakukan oleh (Surijah et al., 2017) dengan judul Membedah Instagram: Analisis Isi Media Sosial Pariwisata Bali. Penelitian ini mengkaji elemen foto dan teks yang terdapat pada Instagram dengan cara mengelompokkan akun yang menjadi unit penelitian.

Teknik analisis isi digunakan untuk mengamati pesan-pesan yang disampaikan oleh social media influencer, terkait dengan sejumlah aspek penting. Penggunaan analisis isi kualitatif memungkinkan penulis melihat isi pesan secara lebih dalam, melalui pemahaman makna pesan, termasuk pemahaman aspek sintaksis dan semantik dari pesan-pesan tersebut. Lebih jauh penggunaan analisis isi kualiatif menjadikan penulis bisa memberikan interpretasi secara benar tentang pesan-pesan yang disampaikan, sehingga membantu peneliti untuk menafsirkan pesanpesan yang ada sebagai suatu cara untuk memahami peran social media influencer ketika memberikan informasi kepada khalayak.

Penelitian ini mengambil social media influencer instagram @graciaindr sebagai subyek utama dalam penulisan penelitian ini.
Akun tersebut nampaknya ingin mencoba merubah kesadaran akan standar kecantikan terhadap rambut yang selama telah terbentuk serta dan mempersuasi para pengikutnya untuk menggali kecantikan rambut keriting mereka. Hal itu menjadikan penulis tertarik untuk mengamati dan menjelaskan sebagian dari aktivitas yang dilakukan oleh @graciaindr, khususnya terkait dengan usahanya menyebarkan pemahaman baru tentang konsep kecantikan wanita Indonesia khususnya dalam hal rambut. Penggunaan analisis isi kualitatif dilakukan oleh penulis untuk membantu peneliti untuk menafasirkan atau menginterpretasikan pesan-pesan yang diberikan oleh social media influencer. Penelitian ini mengamati unggahan yang terdapat dalam akun Instagram serta dari pemberitaan yang ada di media online. Pemilihan unggahan dilakukan secara purposif didasari oleh tingkat kepentingan pesan, jumlah liked postingan, dan sejumlah hal hal lain yang membantu penulis dalam menentukan tingkat kepentingan pesan.

\section{HASIL DAN PEMBAHASAN \\ Sosial Media Influencer dalam Membangun Narasi}

Temuan yang dapat diperoleh gambaran yang menyeluruh mengenai sosial media influencer dalam membangun narasi untuk mempersuasi khalayak dengan mengunakan pesan-pesan terkait konsep kecantikan. Pembahasan dalam tulisan ini fokus pada penggunaan pesan-pesan persuasif yang dilakukan oleh akun @graciaindr sebagai upaya menarik perhatian khalayak. Selain itu, penulis juga tertarik untuk melihat tanggapan khalayak atas postingan atau informasi yang disajikan oleh akun @ graciaindr. Selama ini pandangan umum yang ada pada masyarakat adalah bahwa rambut yang cantik adalah rambut yang hitam dan lurus. Padahal kenyataannya di Indonesia sendiri banyak orang yang memiliki rambut yang keriting. 
Kenyataan inilah yang mendorong social media influencer yakni@graciaindr untuk membangun pemahaman bahwa rambut keriting dapat menjadi cantik juga. Gracia saat ini memiliki 16.000 pengikut di akun media sosial instagram.

Hal ini sependapat oleh Gusti Ayu Wulandari (Zulfikar, 2017) konsep pemasaran social marketing secara sederhana diartikan sebagai strategi untuk mengubah sikap dan perilaku sosial. Dengan didukung media pemasaran yang saat ini sedang berkembang pesat yaitu media sosial seperti Instagram, sangat efektif dimanfaatkan pada lembaga nirlaba. Social marketing tidak ditujukan untuk mencari laba yang bertugas untuk meningkatkan kemampuan mengomunikasikan gagasan-gagasan yang nantinya akan dilemparkan kepada masyarakat dalam rangka meningkatkan kualitas kehidupan. Menurut Mayfield (Catur Bagus Wicaksono, 2013) social media paling baik dipahami sebagai suatu kelompok baru dari online media, yang sebagian besar memiliki karateristik sebagai berikut: (a) Participation \& Engagement, social media mendorong kontribusi dan umpan balik dari semua orang yang tertarik. Hal ini mengaburkan batas antara media dan audiens. (b) Openness, sebagian besar layanan social media terbuka untuk menerima umpan balik dan partisipasi. Media social mendorong suara/voting, komentar, dan berbagai informasi. Terdapat sedikit hambatan untuk mengakses dan membuat konten, bahwa konten tersebut dilindungi dengan password dari pengguna, (c) Conversation, bila tradisional media berbicara tentang komunikasi broadcast (konten yang ditransmisikan atau didistribusikan kepada audiens), social media berbicara tentang komunikasi yang lebih baik, yaitu menggunakan metode percakapan komunikasi 2 arah, (d) Community; Social media memungkinkan komunitas untuk terbentuk dengan cepat dan dapat berkomunikasi dengan efektif. Komunitas dapat berbagi minat yang sama, seperti pencinta fotografi, olahraga, atau sebuah acara tv favorit, (e) Connectedness; social media berkembang karena keterhubungan mereka satu dengan lain dengan cara memanfaatkan link yang mengarahkan untuk berpindah ke sumber website yang lain.

Fakta tersebut sejalan dengan apa yang disampaikan oleh Ardianto (Afrilia, 2018) bahwa media sosial sebagai media yang memiliki kekuatan sosial untuk memengaruhi opini publik yang berkembang di masyarakat. Penggalangan dan dukungan atau gerakan massa dapat terbentuk karena kekuatan media online. Apa yang ada di dalam media sosial terbukti mampu membentuk opini, sikap, dan perilaku publik/masyarakat. Berdasarkan dari hasil penelitian tersebut sependapat dengan Elfiky (Girindra et al., 2018) kepercayaan diri adalah berbuat dengan penuh keyakinan, apa pun tantangan yang dihadapi dan dalam kondisi apa pun, kekuatan yang mendorong seseorang untuk maju dan berkembang serta selalu memperbaiki diri. Menurut Michael Argyle dan Lanet Dean (Monica, 2020) mengemukakan suatu teori komunikasi nonverbal yang didasarkan pada suatu metafora keintiman - equilibrium, bahwa setiap kali kita berinteraksi kita mengalami atau menggunakan seluruh saluran komunikasi yang ada, dan suatu perubahan dalam suatu saluran nonverbal akan menghasilkan perubahan pada saluran komunikasi yang ada dan suatu perubahan dalam suatu saluran nonverbal akan menghasilkan perubahan pada saluran lainnya sebagai kompensasi, misalnya pendekatan dan penghindaran. Kusuma Jaya (Sari, 2019) mengatakan bahwa kecantikan itu pada hakikatnya adalah kemampuan tampil menarik secara keseluruhan, bukan bagian per bagian. Hal ini senada dengan (Hapsari \& Sukardani, 2018) mendefinisikan bahwa kecantikan pada masa itu adalah wanita dengan tubuh yang gemuk dan jauh dari kata 
langsing. Ashad Kusuma Djaya (Wiasti, 2012) bahwa kecantikan adalah total, mencakup ukuran-ukuran tubuh (fisik), dan mental atau kepribadian (inner beauty) dengan ukuran standar pula, sehingga secara keseluruhan melahirkan kecantikan sejati. Kondisi ini sudah menyangkut estetika yang mengandung unsur obyektif dan subyektif.

Hal senada diungkapkan oleh Boyd yang menjelaskan bahwa media sosial sebagai kumpulan perangkat lunak yang memungkinkan individu maupun komunitas untuk berkumpul, berbagi, berkomunikasi, dan dalam kasus tertentu saling berkolaborasi atau bermain. Media sosial memiliki kekuatan pada user generated content (UGC) di mana konten dihasilkan oleh pengguna, bukan oleh editor sebagaimana di institusi media massa.(Harista, 2017)

\section{Komunikasi Persuasi Influencer}

Gracia secara konsisten memusatkan memusatkan perhatian pada usaha untuk mengubah cara pandang khalayak mengenai rambut keriting. Sejumlah fakta bahwa mayoritas pesan yang diberikan oleh Gracia dalam akun media sosialnya merupakan bentuk komunikasi persuasif. Hal ini ditunjukkan dengan postingan Gracia yang disusun dalam bentuk kalimat-kalimat dengan nada positif. Hal ini dinilai bisa membangun kepercayaan diri bagi khalayaknya.

Pada gambar 1 tentang pesan (Unggahan) dalam akun @graciaindr yang menunjukkan ajakan untuk mencintai dan merawat rambut keriting Gracia menggunakan tagar \#EmbraceYourCurls. Pesan ini merupakan ajakan untuk bersamasama mencintai dan merawat rambut keriting. Jika dikaitkan dengan faktor sosial media influencer, hal ini berkaitan dengan dengan faktor relevance. Dimana postingan tersebut sangat memiliki kekuatan yang erat dengan topik mengenai rambut keriting. Hal ini ditunjukkan dengan tampilan Gracia yang menonjolkan sisi keriting dari rambutnya. Ia juga menambahkan dengan hiasan berbentuk hati supaya khalayak semakin fokus pada bagian rambutnya. Sehingga penggambaran tersebut terlihat tampilan yang menarik dari rambut keriting. Tagar ini seolah menyemangati pengikut akun Gracia supaya mencintai dan merawat rambut sehingga menimbulkan rasa percaya diri.

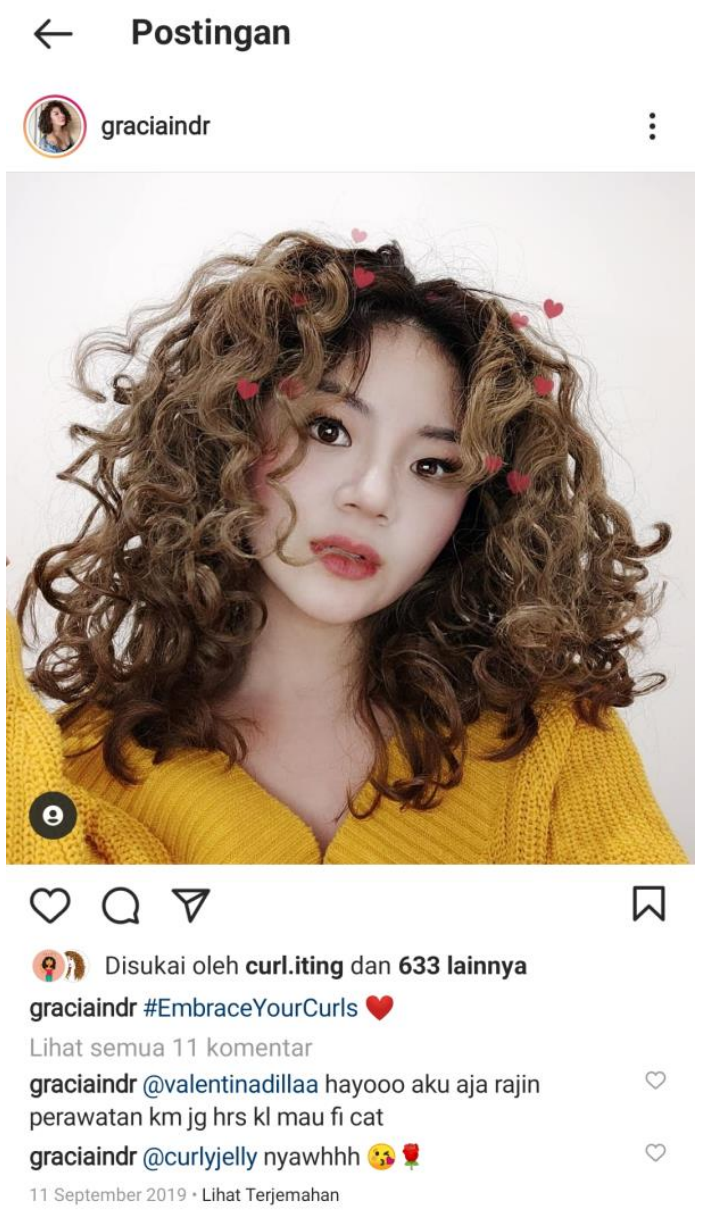

Gambar 1. Pesan (Unggahan) dalam akun @ graciaindr yang menunjukkan ajakan untuk mencintai dan merawat rambut keriting 2020 .

Dalam salah satu wawancara dengan salah satu media online, Gracia juga menyampaikan bahwa untuk memiliki kepercayaan diri memang tidak mudah, namun dapat dilatih dengan cara meningkatkan sikap positif. Hal itu ditunjukkan dalam kutipan berikut "Percaya diri itu gak dateng gitu aja. Rasa percaya diri itu memang perlu dilatih, sih. Yang terpenting, surround yourself with positivity, kalian harus hidup untuk diri sendiri." Ia juga menceritakan bagaimana dirinya dahulu tidak memiliki rasa percaya diri justru malah 
merasa sedih dan malu ketika berkaitan dengan penampilan rambutnya. Dengan menyampaikan pengalamannya ini, Gracia memposisikan dirinya untuk memahami perasaan khalayak karena dia juga mengalami hal yang sama sehingga dengan menceritakannya ia dapat mengarahkan perilaku khalayak untuk lebih bersikap positif. Hal ini berkaitan dengan faktor resonance dimana influencer memiliki kemampuan untuk mempengaruhi serta merubah perilaku yang diinginkan dari khalayak.

Ia juga membagikan pengalaman bahwa dirinya merasa kecewa dan sedih ketika dirinya melakukan perawatan di salon justru tidak mendapatkan solusi bagaimana merawat rambut keritingnya dengan cara yang tepat, baik serta benar. Terlebih lagi, ia juga kerap kali merasa bahwa rambut keritingnya adalah kutukan. Hal ini terlihat dari kutipan "Dulu, aku selalu nangis keluar dari salon. Aku selalu kecewa karena aku dateng ke salon itu untuk mencari solusi, sedangkan aku gak pernah dapet solusi yang aku butuhin. Mereka selalu menyarankan aku untuk meluruskan rambut. Aku bahkan sampe merasa rambut keriting aku seolah kutukan." Pengalaman yang ia ceritakan ini menciptakan emosi haru dan membangkitkan perasaan senasib dengan khalayaknya yang mengalami atau juga memiliki rambut keriting. Emosi ini menciptakan keterikatan dengan followernya sehingga narasi persuasi selanjutnya yang dia sampaikan dapat lebih diterima oleh khalayak. Pengalaman yang ia bagikan mengenai proses penerimaan keunikan diri dimana dalam hal ini rambut keriting, menjadi momen penting yang membuat Gracia berharap jika semua orang pun bisa berhasil mencintai diri sendiri.

Kredibilitas seorang Gracia dibuktikan dengan postingan dirinya yang sering menjadi narasumber dalam diskusi mengenai kecantikan rambut. Bahkan dia dipasangkan dengan social media influencer terkenal lainnya seperti Agnes Oryza. Bahkan ia juga menambahkan caption pada postingan tersebut bahwa ia akan berbagi pengetahuan yang ia miliki untuk membantu dan mengajarkan khalayak yang mengikuti acara tersebut menjadi lebih paham mengenai rambut mereka. Tampilnya Gracia dalam acara diskusi seperti ini menunjukkan dirinya merupakan influencer yang dapat dipercaya dan yang menguasai mengenai topik perawatan rambut keriting. Meskipun demikian, dalam pengamatan atas postingan yang terdapat pada akun Gracia, kurang terdapat fakta atau bukti maupun pertimbangan logis yang berupa dalam bentuk data yang akurat. Gracia lebih mengedepankan postingan yang berfokus pada bagaimana ia menampilkan dan merawat rambutnya sehingga dia memiliki kepercayaan diri.

Masyarakat memiliki keinginan untuk selalu merubah dan mengikuti hal-hal yang baru. Berbagai barang yang menjadi simbol modernitas, hal itu berakibat pada gaya hidup masyarakat yang mana mengkonsumsi berbagai produk dan benda atau barang yang disebut modern. Salah satu cara mengukur gaya hidup yang modern di tandai dengan gaya berpakain dan gaya rambut. Masyarakat selalu mengubah penampilan mereka sesuai dengan perkembangan zaman. Menurut mereka penampilan adalah nomor satu. (Suprida \& Tamiang, 2020).

\section{Tanggapan Followers Terhadap Unggahan Konten}

Pada gambar 2 tentang acara Let Your Curls Shine tahun 2019 menyebutkan konten postingan yang terdapat pada akun @ graciaindr mengenai rambut keriting dapat terlihat cantik diterima oleh para pengikutnya. Hal ini dapat terlihat dari komentar yang diberikan oleh para pengikut. Meskipun pada sosial media, sangat terbuka kemungkinan bahwa pengikut memiliki kebebasan dalam memberikan tanggapan. Pengikut dari@graciaindr sebagian besar memberikan komentar positif terhadap postingan dirinya. Komentar dari akun firdaus1112 menilai bahwa rambut yang dimiliki oleh Gracia 
sangatlah menarik. Hal ini ditunjukkan dengan ungkapan "So cute curly hair." Komentar lain dari akun sugabsekali yang mengatakan "Ya alaah kapan rambut aku begini." Menujukkan bahwa akun @ graciaindr berhasil mengubah khalayak terhadap penilaian bahwa rambut keriting dapat terlihat cantik dan menawan. Postingan tersebut tersebut juga mendapatkan sejumlah ikon yang menunjukkan komentar positif seperti tanda hati. Selain itu postingan foto dengan caption its okay to have frizzy hair merupakan ajakan untuk mencintai rambut yang keriting dan bahkan menerima rambut yang berkesan kusut.

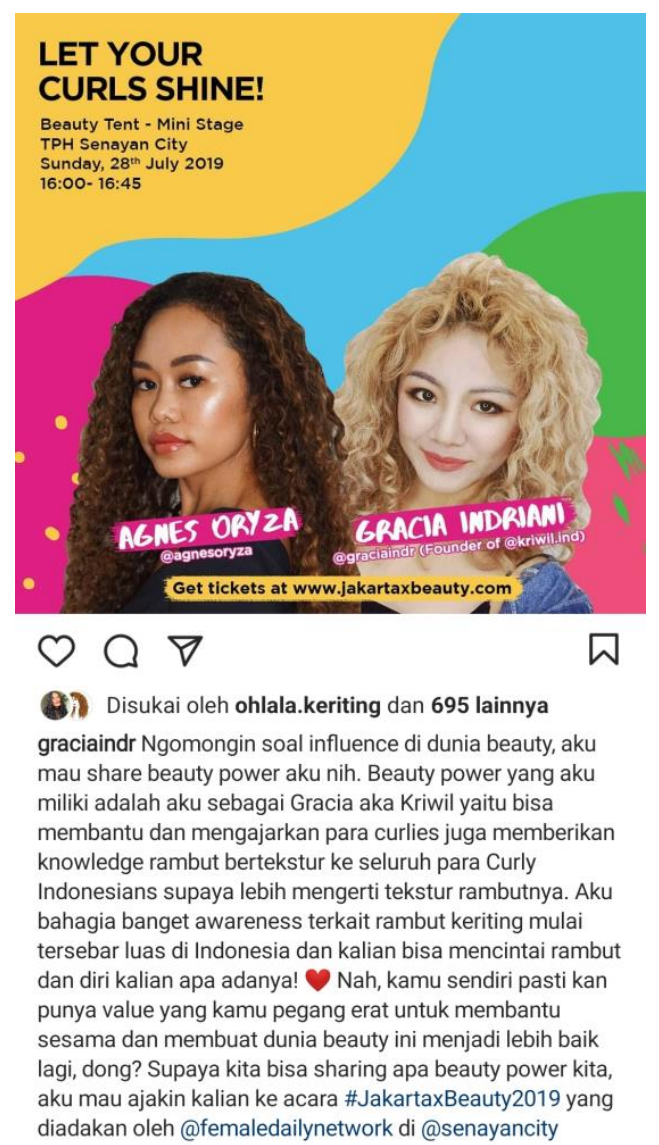

Gambar 2. Acara Let Your Curls Shine 2019.

Berdasarkan dari hasil penelitian sisko (Alala \& Ferdinand, 2016) pengikut media sosial (Followers) tidak menginginkan adanya presentasi penjualan maupun pesan - pesan pemasaran, melainkan ingin adanya obrolan seputar merek yang ditawarkan. Hal tersebut dikarenakan branding melalui internet adalah strategi soft-selling bukan mendorong adanya penjualan Sehingga konten yang menarik dan informatif lebih penting bagi pelanggan yang mengikuti media sosial perusahaan. Pada karakteristik penyesuaian terdapat dua bentuk, yakni penyesuaian diri dan penyesuaian sosial. Menurut (Virgadewi K \& Lestari, 2018) pada penyesuaian diri yang ditemukan pada penelitian ini terdapat penyesuaian diri positif yang meliputi penyesuaian diri pada pekerjaan tahap coba-coba, pengalaman, penjelajahan pekerjaan dan penyesuaian dengan cara bercerita, sedangkan penyesuaian diri negatif meliputi reaksi bertahan. Adanya usaha individu untuk menutupi kesalahan yang diperbuat dan mempertahankan dirinya dengan menyalahkan pelanggan atas kesalahannya. Pada penyesuaian sosial, ditemukan terdapat penyesuaian sosial yang ditunjukkan dalam tiga bentuk yaitu yang pertama relasi ditempat kerja.

Berdasarkan gambar 3 di atas tentang tanggapan dari follower lain terlihat dalam postingan pesan pribadi yang ditampilkan dalam bentuk capture. Postingan ini berisikan pujian serta ucapan terimakasih atas upaya yang dilakukan oleh Gracia dalam menginspirasi dan membantu membangun kepercayaan diri follower. Postingan ini menggambarkan bahwa orang lebih mudah dipersuasi oleh orang yang mereka sukai dimana sejalan dengan pernyataan Robert Cialdini dalam hal prinsip liking. Follower Gracia ini menunjukkan perasaan suka sehingga dia terinspirasi atas apa yang disampaikan oleh Gracia. 

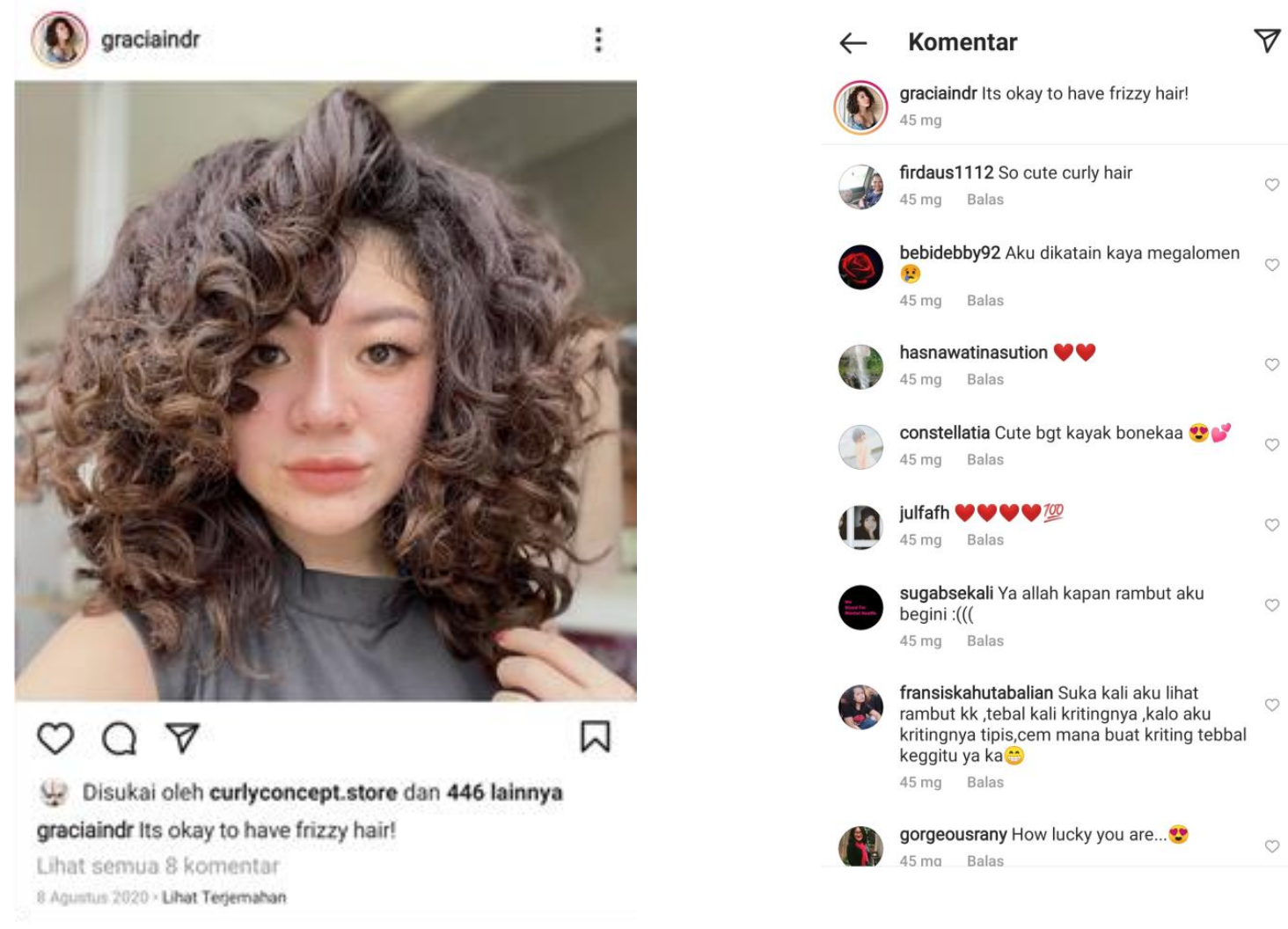

Gambar 3. Tanggapan Follower Graciaindr.

\section{SIMPULAN}

Sosial media influencer dalam membangun narasi untuk mempersuasi khalayak dengan mengunakan pesan-pesan terkait konsep kecantikan. Pembahasan dalam tulisan ini fokus pada penggunaan pesanpesan persuasif yang dilakukan oleh akun @ graciaindr sebagai upaya menarik perhatian khalayak. Salah satunya instagram yang memungkinkan terjadinya komunikasi secara dua arah dan bersifat terbuka. Hal inilah yang memungkinkan munculnya influencer merupakan sosok orang yang memiliki kemampuan untuk memberikan pengaruh serta dampak bagi para pengikutnya. Hasil penelitian ini menunjukkan bahwa memanfaatkan instagram, influencer dimungkinkan untuk menyusun dan membuat konten sendiri. Oleh karena itu, instagram banyak digunakan oleh sosial media influencer dalam menyebarkan narasi maupun konten. Instagram dimanfaatkan sebagai media dalam mengkomunikasikan pesan yang bersifat persuasif dari sosial media influencer.
Penelitian selanjutnya dapat mengembangkan data dan ide penelitian mengenai narasi persuasi sosial media influencer dalam menggunakan data yang lebih banyak dan beragam pengukuran efektivitas sosial media influencer.

\section{DAFTAR PUSTAKA}

Afrilia, A. M. (2018). Personal Branding Remaja di Era Digital. Mediator: Jurnal Komunikasi, 11(1), 20-30. https://doi.org/10.29313/mediator.v11 i1.3626

Alala, L. S., \& Ferdinand, A. T. (2016). Memperkuat keputusan pembelian jasa urbancut barbershop melalui mediasi citra toko. Diponegoro Journal Of Management, 6(1), 1-11.

Alvonco, J. (2014). Sistem Komunikasi Model Umum dan HORENSO untuk Sukses dalam Bisnis, Organisasi dan Kehidupan. PT Elex Media Komputindo. 
Berger, A. A. (2010). The Objects of Affection: Semiotics and Consumer Culture. Palgrave Macmillan.

Bruns, I. (2018). 'Trust' and 'perceived authenticity' in social media driven influencer marketing and their influence on intentions-to-buy of 1824-years-olds in Ireland.

Castells, M. (2013). Communication power. Oxford University Press .

Catur Bagus Wicaksono, K. (2013). Mengukur Efektivitas Social Media Bagi Perusahaan. Binus Business Review, 4(1), 551-564. https://doi.org/10.21512/bbr.v4i1.141 9

Devito, J. A. (2011). Komunikasi Antarmanusia. Kuliah Dasar.

Elli, D. M. (2017). The phenomenon and rise of influencer marketing and how it affect customer opinion and helps or damages brands. International Hellenic University.

Flew, T. (2018). New Media; An Introduction. Oxford University Press.

Girindra, A., Weliangan, H., \& Pardede, Y. O. K. (2018). Citra Tubuh Dan Kepercayaan Diri Pada Mahasiswa Pengguna Kosmetik Wardah. Jurnal Psikologi, 11(2), 143-152. https://doi.org/10.35760/psi.2018.v11 i2.2259

Glucksman, M. (2017). The Rise of Social Media Influencer Marketing on Lifestyle Branding: A Case Study of Lucie Fink. Elon Journal of Undergraduate Research in Communications.

Hapsari, A. B., \& Sukardani, P. S. (2018). Representasi Konsep Kecantikan Perempuan Di Era Millennials Melalui Beauty Influencer Pada Media Sosial Instagram ( Analisis Semiotika Roland Barthes pada Akun Instagram@sarahayuh_, @ abellyc , dan Ayustin Budi Hapsari Abstrak. Commercium, 2(2), 59-62.

Harista, E. (2017). Pengunaan Bahasa
Persuasi di Media Sosial dalam Berdakwah pada Akun Facebook 'Yusuf Mansur (Official).' Jurnal Dakwah Dan Pengembangan Sosial Kemanusiaan, 8(2), 308-324.

Holmes, D. (2012). Teori Komunikasi. Pustaka Pelajar.

Indrawan, J., \& Ilmar, A. (2018). Kehadiran Media Baru ( New Media ) DALAM PROSES KOMUNIKASI POLITIK Studi Ilmu Politik , Universitas Pembangunan Nasional "Veteran" Jakarta ; 2 Program Studi Ilmu Politik Sekolah Tinggi Ilmu Pemerintahan Abdi Negara ( STIP-AN ). Medium, 8(1), 11-17.

Jamiluddin, J. (2017). Problem Pendidikan Anak Tenaga Kerja Wanita Indonesia (TKWI) di Desa Keruak Kecamatan Keruak Kabupaten Lombok Timur. FONDATIA.

https://doi.org/https://doi.org/10.3608 8/fondatia.v1i1.84

Kadekova, Z., \& Hoilencinova, M. (2018). Influencer marketing as a modern phenomenon creating a new frontier of virtual opportunities. Communication Today.

Malau, R. M. U. (2011). KHALAYAKMEDIA BARU. THE MESSENGER, 2(2), 51-56. $\mathrm{http}: / / \mathrm{dx}$.doi.org/10.1016/j.encep.201 2.03.001

Melliana, A. (2006). Menjelajah Tubuh: Perempuan dan Mitos Kecantikan. LKis.

Monica, R. M. (2020). Makna Make-Up Korea Bagi Mahasiswi Ilmu Komunikasi Universitas Singaperbangsa Karawang. JPRMEDCOM: Journalism, Public Relation and Media Communication Studies Journal, 2(2), 69-79.

Sari, I. P. (2019). Rekonstruksi dan Manipulasi Simbol Kecantikan. Hawa, $\quad$ 1(1). https://doi.org/10.29300/hawapsga.v1 i1.2221 
Supradono, B., \& Hanum, A. N. (2011). Peran Sosial Media Untuk Manajemen Hubungan dengan Pelanggan Pada Layanan ECommerce. Value Added Majalah Ekonomi Dan Bisnis.

Suprida, E., \& Tamiang, A. (2020). Bosan Dengan Rambut Hitam: Kajian Budaya Tentang Tren Mewarnai Rambut Di. 4(1), 110-121.

Surijah, Edwin, A., \& Dkk. (2017). Membedah Instagram: Analisis Isi Media Sosial Pariwisata Bali. Jurnal Psikologi Ilmiah. http://journal.unnes.ac.id/nju/index.ph $\mathrm{p} / \mathrm{INTUISI}$

Suryani, T. I. (2020). Representasi Perempuan Tangguh Dalam Iklan Shampo "Pantene Pro-Vitamin Series." Jurnal Komunikasi Dan Kebudayaan, 7(1).

Usmita, F. (2007). Disengagement; Strategi Penanggulangan Terorisme di Indonesia. Jurnal Sosiologi, 17(1),
$49-63$.

Virgadewi K, I. A. A. W., \& Lestari, M. D. (2018). Penyesuaian Diri dan Penyesuaian Sosial Penata Rambut Laki-Laki. Jurnal Psikologi Udayana, $5(2)$, https://doi.org/10.24843/jpu.2018.v05 .i02.p10

West, R., Lynn, H., \& Turner. (2019). Introducing Communication Theory. McGraw Hill.

Wiasti, N. M. (2012). Redefinisi Kecantikan Dalam Meningkatkan Produktivitas Kerja Perempuan Bali di Kota Denpasar. Piramida, 6(2), 1-22.

Zulfikar, A. R. (2017). Pengaruh social Media Marketing Terhadap Brand Trust Pada Followers Instagram dompet dhuafa Cabang Yogyakarta. $A L$ IDARAH: JURNAL MANAJEMEN DAN ADMINISTRASI ISLAM, 11(1), 92-105. 